\title{
DESTINATIONS' COMPETITIVENESS THROUGH TOURIST SATISFACTION: A SYSTEMATIC MAPPING STUDY
}

\author{
Hardinata Cosvi ${ }^{\star}$, Hermanto Bambang, Sukoco Iwan, Zultaqawa Zeis \\ Department of Business Administration, University of Padjadjaran, Bandung, Indonesia \\ ${ }^{*}$ E-mail: cosvieh@gmail.com \\ ORCID: 0000-0002-9106-9390
}

\begin{abstract}
The concept of tourism competitiveness is not only related to the economic sector but also directly related to social and cultural aspects. Tourism destinations have been developed at an industrial level, where destination management involves various aspects of the sector at domestic and international levels so that it needs to be studied more deeply for practitioners and academics. Therefore, this article aims to classify, identify scientific publications and conduct a systematic analysis of the current literature, to create extensive and detailed understanding. The research method is carried out with a systematic mapping study (SMS) technique to find research trends and look for the state of the art from the field of tourist satisfaction and destination competitiveness. The research method adopted by SMS is a practical research method to identify the right topics to be researched, and which areas are needed for more research by examining scientific publications produced based on the focus and type of research from time to time. The results of this study provide guidance to assist researchers in planning future research through the discovery of research gaps. This Systematic Mapping Study procedure follows relevant empirical guidelines and maps articles in Scopus's electronic database. Furthermore, the researchers examined all articles published in various international journals published by Scopus in the last 10 years. Articles are chosen according to the criteria of the relevant tourist satisfaction and destination competitiveness studies, the final findings of which are 54 articles that match the inclusion criteria. The author classifies articles in six categories, namely research trends from year to year, country of publication, type of article, research approach, research focus and research locus.
\end{abstract}

\section{KEY WORDS}

Systematic mapping study, research gaps tourism, destination competitiveness, tourist satisfaction, tourism, Indonesia.

Tourism is one of the largest and fastest growing industries in the world, this sector contributes greatly to economic development, poverty reduction, employment and various other positive impacts (economic, social, political and cultural) (Cooper \& Hall, 2007; Vuuren \& Slabbert, 2011). The vital role of the tourism sector requires all parties or stakeholders to develop this sector sustainably. In addition to the important role and positive impact produced by the tourism sector, if it is not managed with a sustainable principle, the tourism sector can harm local communities, the natural environment and the economy (Ratman, 2016).

The tourism system as an industry consists of a demand and supply subsystem. The aspect of travel deals is closely related to the activities of providing tourist attractions, tourism services such as guides, hotel facilities, restaurants, conditions and means of transportation to tourist attractions. These needs are the supply produced by producers and are a unitary entity that tourists must obtain together (Graham, Nilsen, \& Payne, 1988). Thus it is said that tourism products are complex, component production is handled by various agencies both government and private, individuals and groups (Octavia et al., 2016).

The number of emerging destinations for regional, national and international scales makes tourism destinations have very tight competitors. Tourism competitiveness can be interpreted as the ability of tourist destinations to sell tourist facilities and tourism services 
better than other destinations in tourism experiences that are considered important by tourists (Knežević Cvelbar, Dwyer, Koman, \& Mihalič, 2016). Tourist satisfaction is very important for the competitiveness of a tourism destination because it will directly influence the choice of destinations, re-visit intention which ultimately results in loyalty (Yoon \& Uysal, 2005; Agyeiwaah, Adongo, Dimache, \& Wondirad, 2016; Sheng \& Chen, 2012; Chen \& Chen, 2010; Kotler \& Keller, 2016).

The purpose of this systematic mapping study is to shape the background of further research and gain deeper insight into destination competitiveness. In the search, researchers used electronic databases to find articles that discussed destination competitiveness. SMS study is the right method as a literature study approach because it is supported by articles from searches in Scopus electronic database.

The research questions in this systematic mapping study are far broader than SLRs to discuss the broader scope of research (Barbara Kitchenham \& Charters, 2007). The research questions from this study concentrate on categorizing topics related to destination competitiveness. Overall researchers analyzed the search results of article searches with the main questions (Research Questions) in this study include:

1. RQ1: How are the trends of publication of each year?

2. RQ2: How is the trend of the country publication of origin?

3. RQ3: How are the types of publication articles studied?

4. RQ4: How is the research approach carried out?

5. RQ5: How is the focus of the research on the topic studied?

6. RQ6: How is the research locus on the topic studied?

The results of this study provide a comprehensive research approach to destination competitiveness as well as implications and guidelines for academics and other practitioners.

\section{LITERATURE REVIEW}

Based on a search of several sources of research conducted, researchers found that the research to be carried out was adapted from a part of the model integrated with destination competitiveness consisting of inherited resources, resources created, supporting factors and other resources as determinants of competitiveness the destination to be done, The only difference is only the description terms used by researchers and other studies that also identify resource objectives as an important factor in determining competitiveness, as done by (Armenski, Dwyer, \& Pavluković, 2018; Armenski, Gomezelj, Djurdjev, Ćurčić, \& Dragin, 2012; Ritchie \& Crouch, 2003; Wilde \& Cox, 2008; Larry Dwyer \& Kim, 2003; L Dwyer, Livaic, \& Mellor, 2003; Buhalis, 2000; Hassan, 2000; Kozak \& Rimmington, 1999). In this case, it examines the factors that influence destination competitiveness from a tourist perspective (demand side).

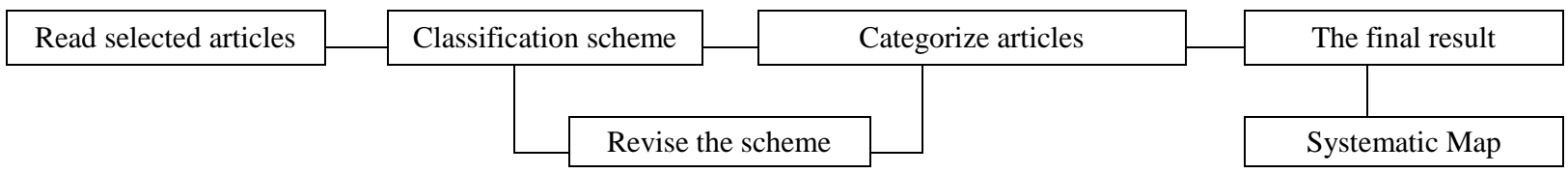

Figure 1 - Classification Process

Referring to the systematic literature review / SLR method (Barbara Kitchenham \& Charters, 2007) literature reference sources are based on database journals spread in digital libraries such as; Scopus, Elsevier, MDPI, Wiley Online Library, SAGE Journals, ScienceDirect, Emerald Insight. Researchers choose publication articles that are relevant to the topic under study and categorize findings based on suggestions from (Banaeianjahromi \& Smolander, 2014).

This study refers to research conducted and according to instructions by (Kitchenham, 2004; Petersen, Feldt, Mujtaba, \& Mattsson, 2008; Banaeianjahromi \& Smolander, 2016), every step of systematic mapping will have results up to the final results of mapping processes to determine research gaps. 
In the systematic propagation process, to analyze and classify articles that have been selected based on criteria, researchers develop a classification scheme that refers to (Petersen et al., 2008). The process of classifying articles is illustrated in Figure 1.

\section{METHODS OF RESEARCH}

This study uses a systematic mapping study (SMS) method which is a secondary study. SMS is rooted in a study literature review (SLR) introduced in medical research (Barbara Kitchenham, 2004). The application of SLR is to identify, evaluate, and interpret all available and relevant literature related to research questions or domains of interest (Barbara Kitchenham \& Charters, 2007)(Petersen et al., 2008). The most common reasons for conducting an SLR are: first, summarize the available evidence on the topic; Second, to identify gaps in current research and provide suggestions for future investigations; And third, to provide a background for positioning new research activities (Barbara Kitchenham, 2004; 2007; 2009; 2011; 2013).

SMS is applied to describe the types of research activities that have been carried out in this study. SMS describes research at a high level and maps research from investigating research questions in detail (Petersen et al., 2008). In other words, SMS can be considered as a method to get an overview of a particular area of research (B. Kitchenham et al., 2011), because, SMS research explores information in detail (Barbara Kitchenham \& Brereton, 2013).

\section{RESULTS AND DISCUSSION}

This systematic mapping study provides an overall picture of destination competitiveness. Researchers from academia and practitioners can use this research as a reference for conducting research. The researcher examined all articles published in various international journals published by Scopus in the last 10 years. The first step is to define the main keywords, the second step is to examine studies that are well known in the field of destination competitiveness, and the third step is to look for alternative keywords to be used in the search process, the last step using Boolean operators whose function is to synthesize one search, using AND or OR. Articles are selected according to the field of tourist satisfaction and destination competitiveness with search criteria ("tourist satisfaction" AND ("destination competitiveness" OR destination OR competitiveness OR competitive)), the final findings of the relevant article search database using Scopus are 54 articles.

Table 1 - Results of Mapping Tourist Satisfaction and Destination Competitiveness

\begin{tabular}{|c|c|c|c|}
\hline No & Category & Sub Categories & Number of Publications \\
\hline 1 & 2 & 3 & 4 \\
\hline \multirow{4}{*}{1} & \multirow{4}{*}{ Year } & $2008-2010$ & 3 \\
\hline & & $2011-2013$ & 11 \\
\hline & & $2014-2016$ & 14 \\
\hline & & $2017-2018$ & 24 \\
\hline \multirow{16}{*}{2} & \multirow{16}{*}{ Publication Country of Origin } & Australia & 1 \\
\hline & & Bangladesh & 1 \\
\hline & & China & 2 \\
\hline & & Croatia & 1 \\
\hline & & Cyprus & 1 \\
\hline & & Denmark & 1 \\
\hline & & Dominican Republic & 1 \\
\hline & & Ecuador & 2 \\
\hline & & Egypt & 1 \\
\hline & & India & 1 \\
\hline & & Italy & 1 \\
\hline & & Japan & 1 \\
\hline & & Kuwait & 1 \\
\hline & & Malaysia & 7 \\
\hline & & Netherlands & 2 \\
\hline & & New Zealand & 1 \\
\hline 1 & 2 & 3 & 4 \\
\hline 2 & Publication Country of Origin & Portugal & 4 \\
\hline
\end{tabular}


RJOAS, 7(91), July 2019

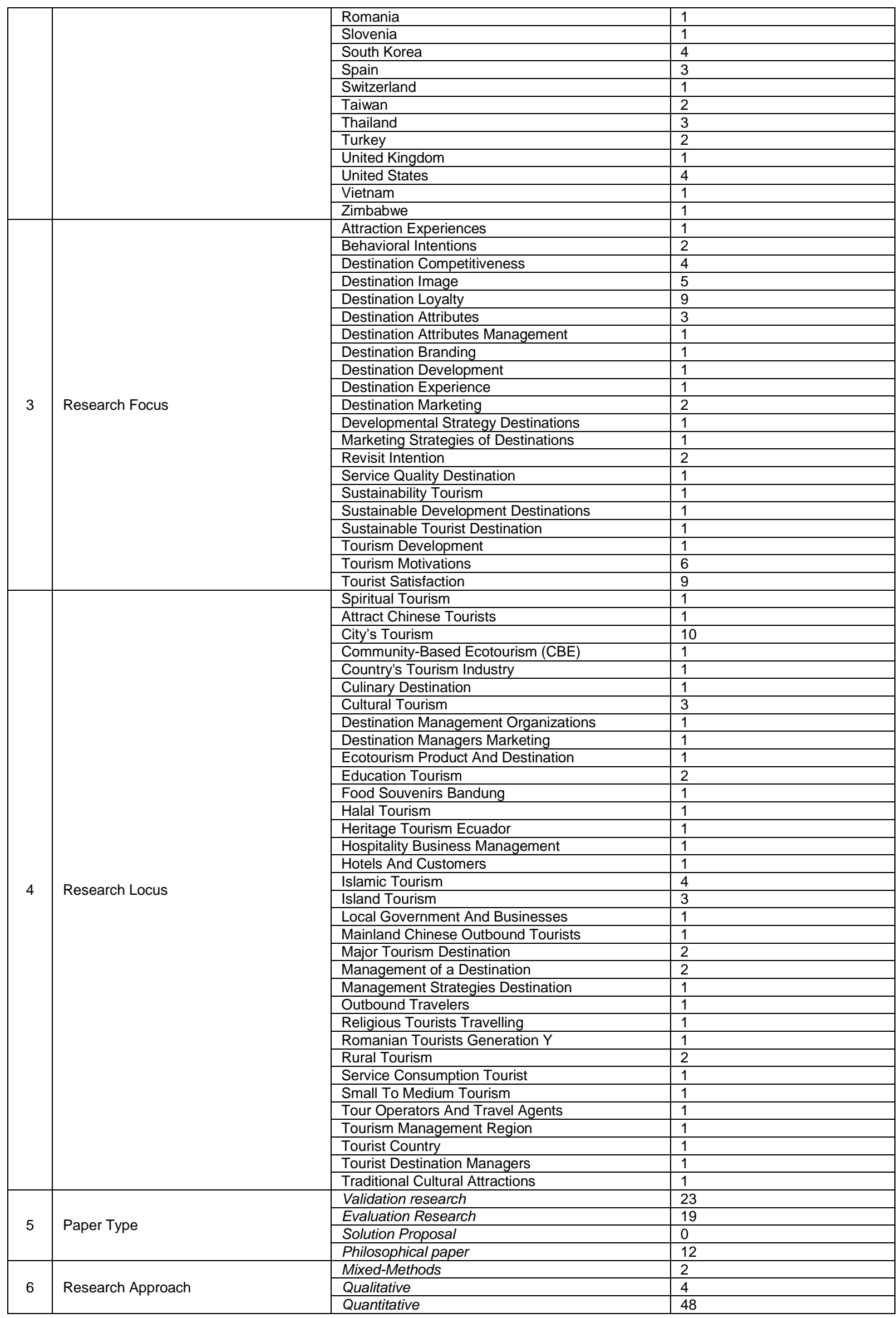

RQ1: How are the trends of publication of each year? 
Based on the results of the mapping study, it can be illustrated the trends in the study of tourist satisfaction and destination competitiveness from 2000 to 2018. The largest publication results were in 2018, 13 research later in 2017 as many as 11 studies, as shown in the following figure 2:

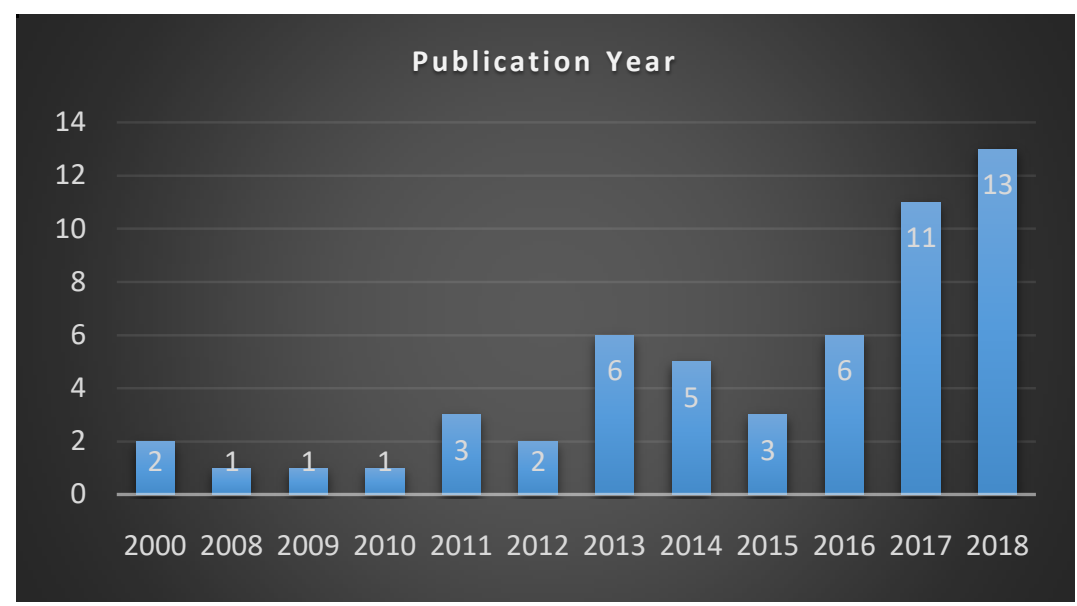

Figure 2 - Research Trends Each Year

RQ2: How is the trend of the country publication of origin?

The grouping of articles based on the state is known that the study of tourist satisfaction and destination competitiveness is generally dominated by 7 scientific articles from Malaysia, followed by Portugal, South Korea, and the United States each with 4 article publications. This condition shows that research on tourist satisfaction and destination competitiveness is a research theme that has received much attention from academics and practitioners in ASEAN with Malaysia representing the largest number of articles, whereas in Indonesia there has been no research on tourist satisfaction and destination competitiveness (Figure 3).

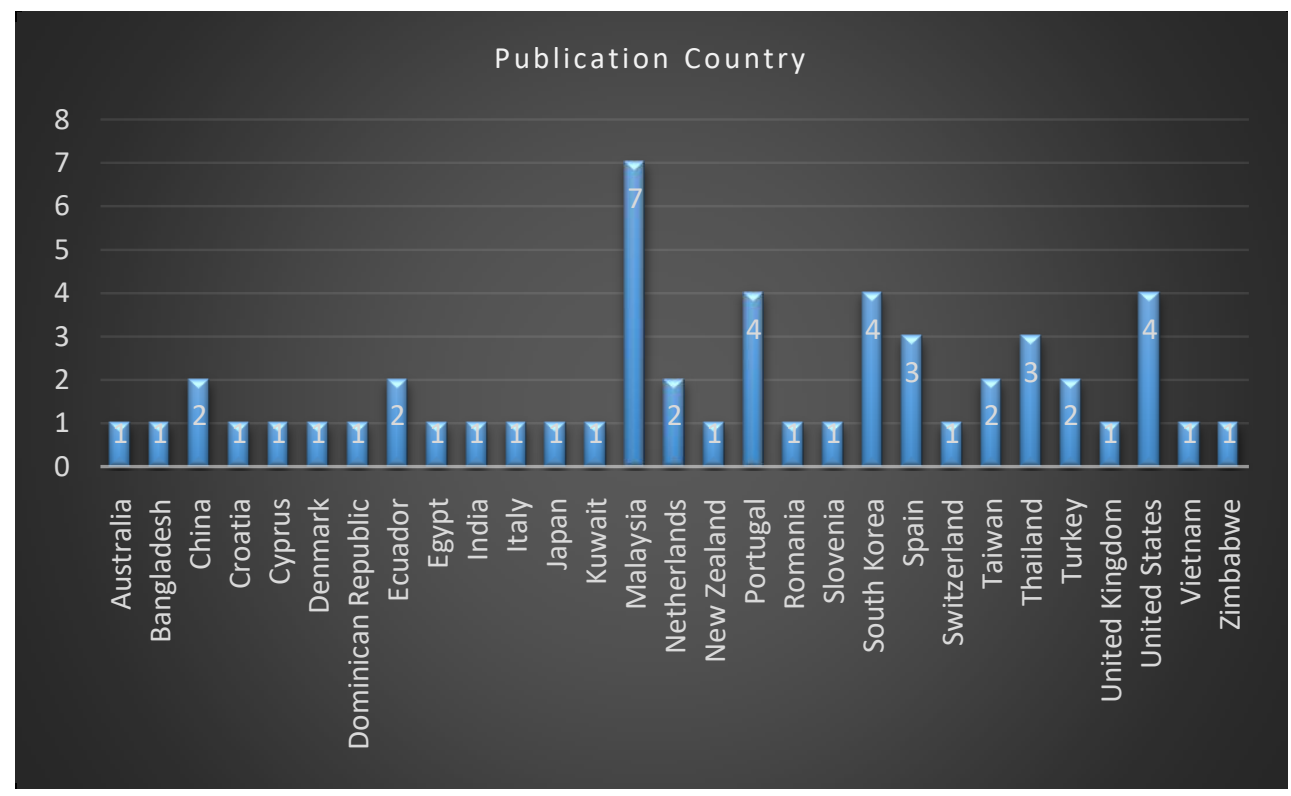

Figure 3 - Publication Country of Origin

RQ3: How are the types of publication articles studied?

Furthermore, the researcher's categorized previous research based on paper type. In figure 4 illustrates the number of types of articles in previous studies regarding tourist satisfaction and destination competitiveness. Based on the systematic mapping results, the 
most frequently used types of articles are 23 article validation, then the 19 evaluation paper types, and 12 articles for philosophical papers, but articles have not been found with the type of solution paper article.

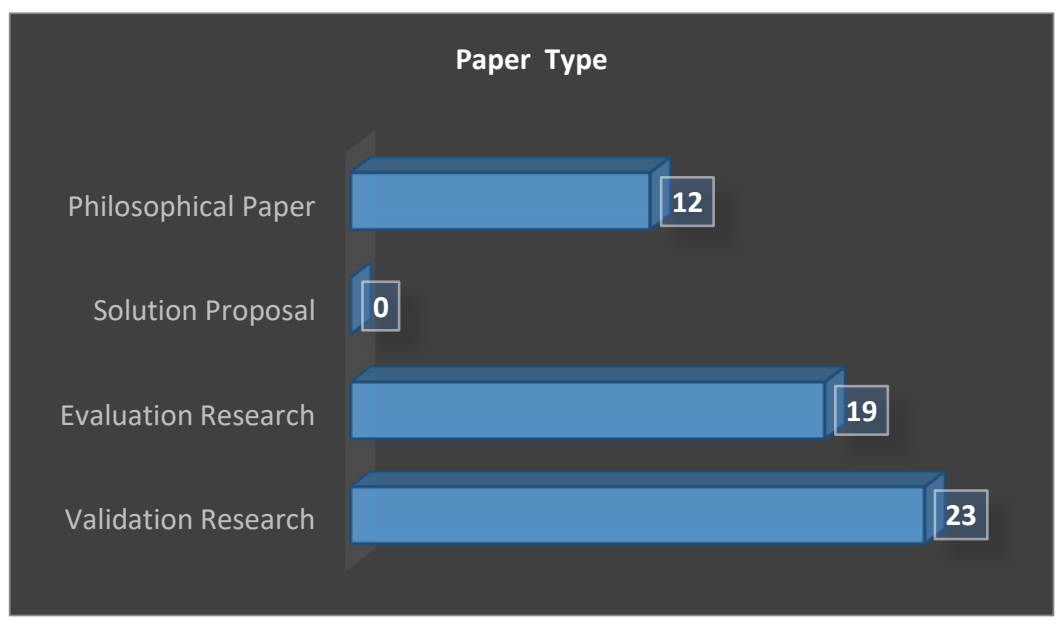

Figure 4 - Types of Articles

RQ4: How is the research approach carried out?

The approach of the research method used in this systematic mapping is quantitative, qualitative and mixed-method approaches. The research approach using quantitative methods is the most widely used method. The total articles that conduct research using a quantitative approach are 48 articles. Then followed by articles using 4 qualitative methods, and mixed methods as many as 2 studies. The total accumulation of findings from 54 articles from the Scopus reputable journal is explained in the following figure 5:

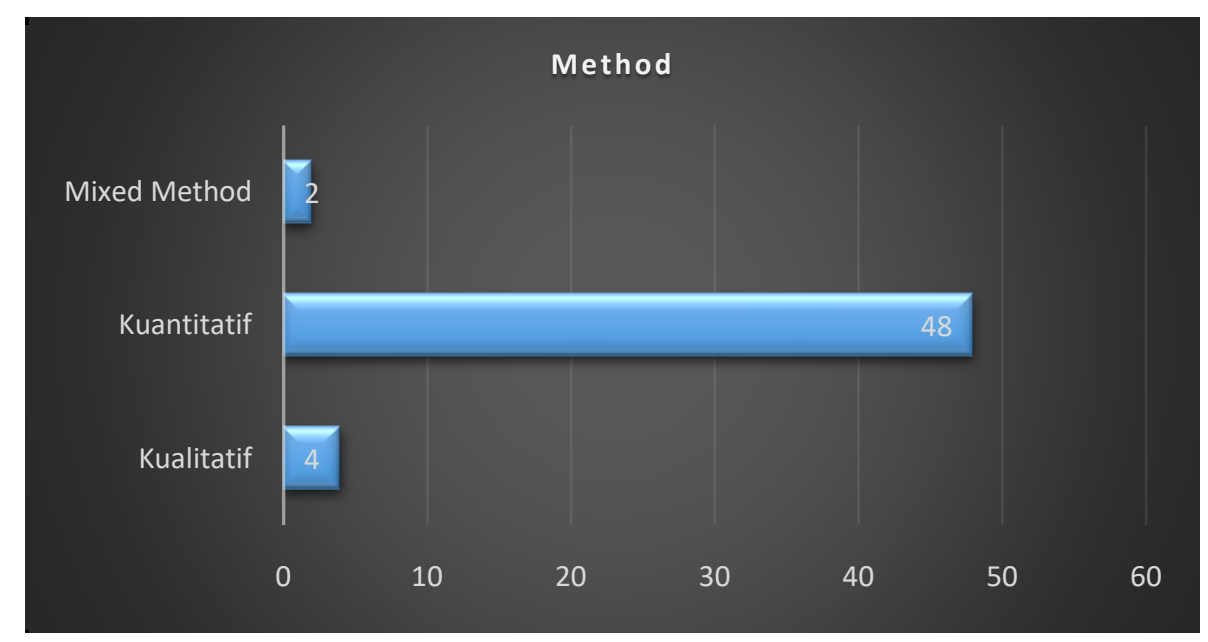

Figure 5 - Research Approach

RQ5: How is the focus of the research on the topic studied?

Grouping articles based on the focus of the research shows that the focus of previous research was on tourist satisfaction and destination competitiveness. Figure 6 shows that the most research focus is found in articles with a focus on research on tourist satisfaction and destination loyalty, each of 9 research articles, 6 research focus on tourist motivation, then destination image research focus of 5 articles and research on destination competitiveness as much as 4 research. 


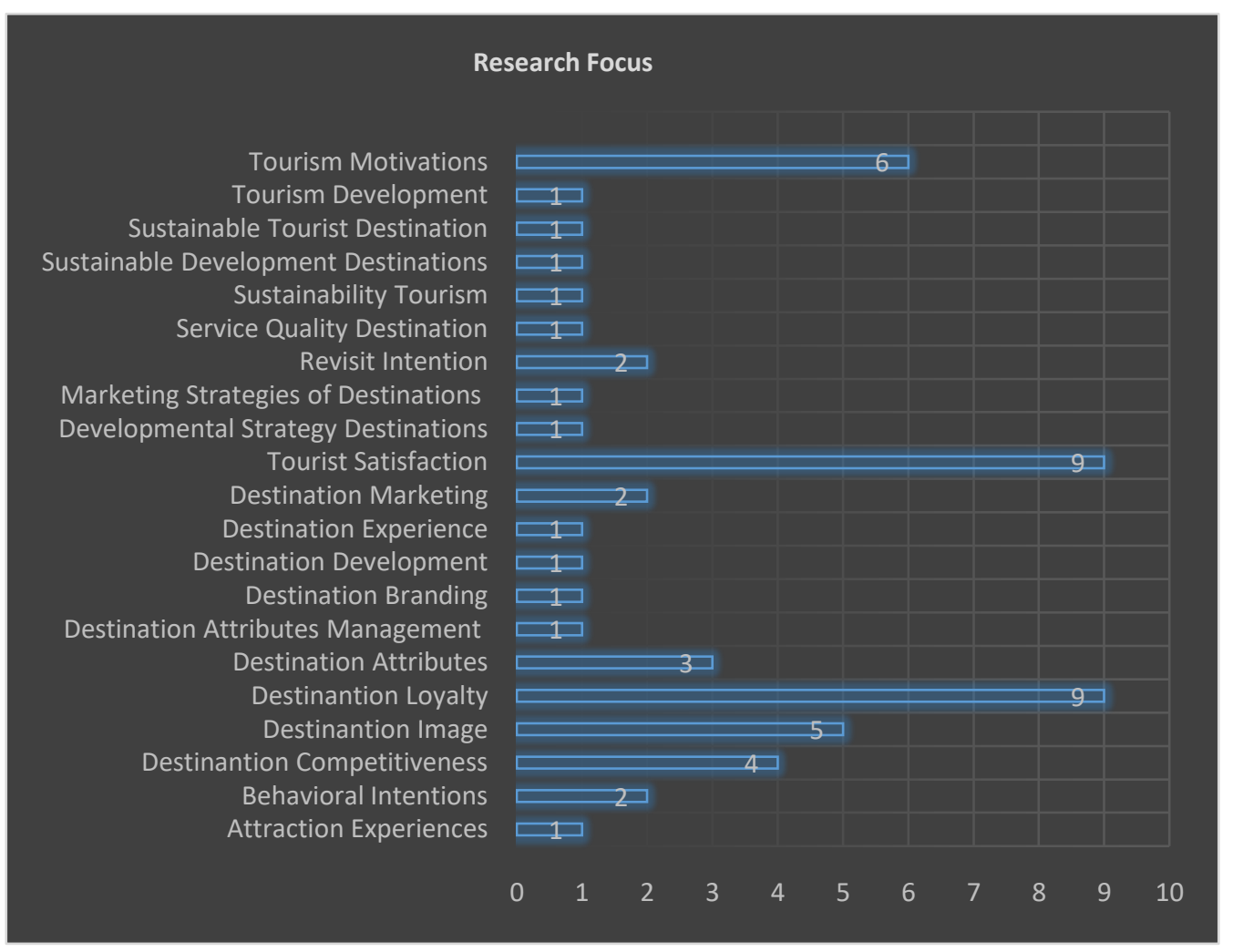

Figure 6 - Research Focus

RQ6: How is the research locus on the topic studied?

Grouping articles based on the research locus in Figure 7 shows that the research of tourist satisfaction and destination competitiveness has 10 articles researching city tourism, Islamic tourism has 4 articles, then cultural tourism and island tourism, each of which has 3 articles.

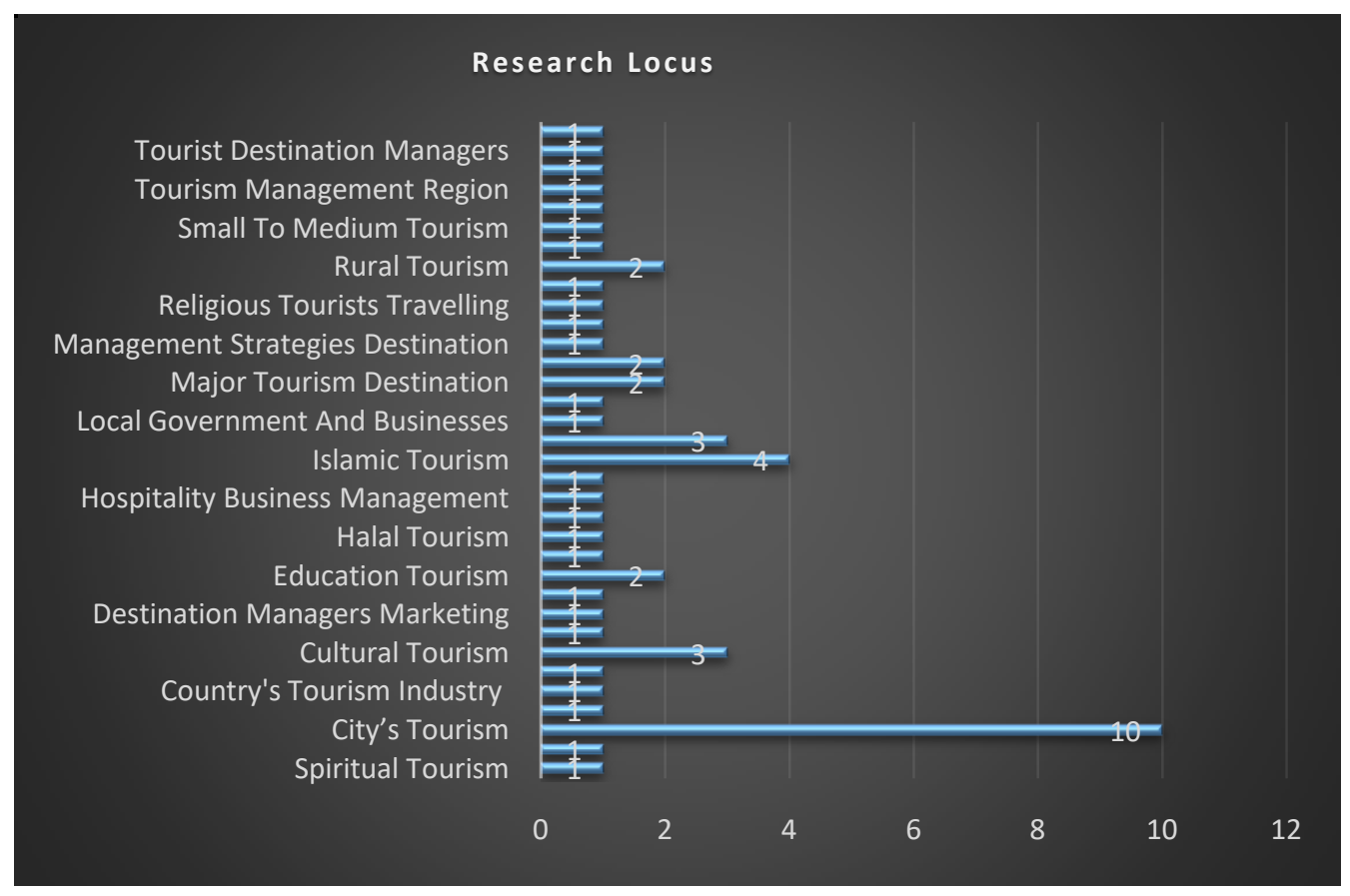

Figure 7 - Research Locus 


\section{CONCLUSION}

The researcher conducted a literature mapping study of destination competitiveness systematically (a systematic literature review). The main motivation of the mapped study is to find research trends and look for the state of the art of tourist satisfaction and destination competitiveness. and as a consideration for academics and practitioners for reference and literature in the field of tourism competitiveness.

Researchers applied the SMS method carried out (B. A. Kitchenham, 2007; Petersen et al., 2008) to determine the focus of what has been studied in this area of research that has been systematically mapped, and then the authors classify it according to article categories such as previous research trends, publication country of origin, type of article, research approach, research method, research focus, and research locus. The research method adopted (SMS) is a practical research method to identify the right topics to study, and which areas are needed for more research. Furthermore, this SMS study will later become the initial reference for research in the field of destination competitiveness. The results of this study provide guidance to assist researchers in planning future research through the discovery of research gaps.

\section{REFERENCES}

1. Agyeiwaah, E., Adongo, R., Dimache, A., \& Wondirad, A. (2016). Make a customer, not a sale: Tourist satisfaction in Hong Kong. Tourism Management.

2. Armenski, T., Dwyer, L., \& Pavluković, V. (2018). Destination Competitiveness: Public and Private Sector Tourism Management in Serbia. Journal of Travel Research.

3. Armenski, T., Gomezelj, D. O., Djurdjev, B., Ćurčić, N., \& Dragin, A. (2012). Tourism destination competitiveness-between two flags. Ekonomska Istrazivanja.

4. Banaeianjahromi, N., \& Smolander, K. (2014). The Role of Enterprise Architecture in Enterprise Integration - a Systematic Mapping. European, Mediterranean \& Middle Eastern Conference on Information Systems 2014 (EMCIS2014), 2014, 1-22.

5. Banaeianjahromi, N., \& Smolander, K. (2016). Understanding obstacles in Enterprise Architecture Development. In ECIS (p. ResearchPaper7).

6. Buhalis, D. (2000). Marketing the competitive destination of the future. Tourism Management. Chen, C. F., \& Chen, F. S. (2010). Experience quality, perceived value, satisfaction and behavioral intentions for heritage tourists. Tourism Management.

7. Cooper, C., \& Hall, C. M. (2007). Contemporary Tourism: An International Approach. Contemporary Tourism: An International Approach.

8. Dwyer, L, Livaic, Z., \& Mellor, R. (2003). Competitiveness of Australia as a tourist destination. Journal of Hospitality and Tourism Management.

9. Dwyer, Larry, \& Kim, C. (2003). Destination competitiveness: Determinants and indicators. Current Issues in Tourism.

10. Graham, R., Nilsen, P., \& Payne, R. J. (1988). Visitor management in Canadian national parks. Tourism Management.

11. Hassan, S. S. (2000). Determinants of market competitiveness in an environmentally sustainable tourism industry. Journal of Travel Research.

12. Kitchenham, B. A. (2007). Kitchenham, B.: Guidelines for performing Systematic Literature Reviews in software engineering. EBSE Technical Report EBSE-2007-01. EBSE Technical Report.

13. Kitchenham, B., Brereton, P., Zhi Li, Budgen, D., \& Burn, A. (2011). Repeatability of systematic literature reviews. In 15th Annual Conference on Evaluation \& Assessment in Software Engineering (EASE 2011).

14. Kitchenham, Barbara. (2004). Procedures for performing systematic reviews. Keele, UK, Keele University, 33(TR/SE-0401), 28.

15. Kitchenham, Barbara, \& Brereton, P. (2013). A systematic review of systematic review process research in software engineering. Information and Software Technology.

16. Kitchenham, Barbara, \& Charters, S. (2007). Guidelines for performing Systematic 
Literature Reviews in Software Engineering. Engineering, 2, 1051.

17. Kitchenham, Barbara, Pearl Brereton, O., Budgen, D., Turner, M., Bailey, J., \& Linkman, S. (2009). Systematic literature reviews in software engineering - A systematic literature review. Information and Software Technology.

18. Knežević Cvelbar, L., Dwyer, L., Koman, M., \& Mihalič, T. (2016). Drivers of Destination Competitiveness in Tourism: A Global Investigation. Journal of Travel Research.

19. Kotler, P., \& Keller, K. L. (2016). MarkKotler, P., \& Keller, K. L. (2016). Marketing Management. Global Edition (Vol. https://doi.org/10.1080/08911760903022556eting Management. Global Edition.

20. Kozak, M., \& Rimmington, M. (1999). Measuring tourist destination competitiveness: conceptual considerations and empirical findings. International Journal of Hospitality Management.

21. Octavia, d., aulia, s., prodi, u., manajemen, s., telekomunikasi, b., \& informatika, d. (2016). Analisa motivasi wisata belanja pada factory outlet di kota bandung. Journal of islamic economics and business).

22. Petersen, K., Feldt, R., Mujtaba, S., \& Mattsson, M. (2008). Systematic mapping studies in software engineering. EASE'08 Proceedings of the 12th International Conference on Evaluation and Assessment in Software Engineering, 68-77.

23. Ratman, D. R. (2016). Pembangunan destinasi pariwisata prioritas 2016 - 2019. Rapat Koordinasi Nasional Kementerian Pariwisata "Akselerasi Pembangunan Kepariwisataan Dalam Rangka Pencapaian Target 12 Juta Wisman dan 260 Juta Wisnus 2016."

24. Ritchie, J. ., \& Crouch, G. (2003). The competitive destination. Tourism Management.

25. Sheng, C. W., \& Chen, M. C. (2012). A study of experience expectations of museum visitors. Tourism Management.

26. Vuuren, c. Van, \& slabbert, e. (2011). Travel motivation and behaviour of tourists to a south african resort. International conference on tourism \& management studies -.

27. Wilde, S., \& Cox, C. (2008). Linking destination competitiveness and destination development: findings from a mature Australian tourism destination. In Proceedings of the Travel and Tourism Research Association (TTRA) European Chapter Conference Competition in tourism: business and destination perspectives.

28. Yoon, Y., \& Uysal, M. (2005). An examination of the effects of motivation and satisfaction on destination loyalty: A structural model. Tourism Management. 